\title{
IMPLEMENTASI PRINSIP MENGENAL NASABAH SEBAGAI UPAYA PENCEGAHAN TINDAK PIDANA PENCUCIAN UANG
}

\author{
M. Rudi Setiawan \\ Magister Kenotariatan Fakultas Hukum Universitas Islam Malang \\ Email: mr.setiawan82@gmail.com
}

\begin{abstract}
Know Your Customer Principles for Non Bank Financial Institutions is one of the efforts to overcome money laundering crime. Iplementation of the principle of knowing customers can be seen through the implementation of customer acceptance policy, the implementation of policies and procedures in identifying customers, implementation of policies and procedures for monitoring of customer accounts and transactions, the implementation of risk management policies and procedures related to the principle of knowing customers. This research is normative law research. The problem approach used is the legal approach and the conceptual approach. Sources of legal materials use primary legal materials and secondary legal materials. Based on the results of research and discussion, it is concluded that in the implementation of customer identification procedures in the application of the principle of knowing customers not only in general Procedure In Bank Indonesia Regulation Number 3/10 / PBI / 2001 but also should be able to dig deeper about the customer itself, because the current technological sophistication also supports the occurrence of money laundering crimes with various forms, so banks should also be able to analyze more detail about the characteristics of customers in anticipation or prevent the emergence of loopholes that can lead to the crime of money laundering.
\end{abstract}

Keywords: bank, know your customer principle, money laundering

\begin{abstract}
ABSTRAK
Prinsip mengenal nasabah bagi Lembaga Keuangan Non Bank merupakan sebagai salah satu upaya untuk menanggulangi tindak kejahatan pencucian uang (money laundering). Penerapan prinsip mengenal nasabah dapat dilihat melalui penerapan kebijakan penerimaan nasabah, penerapan kebijakan dan prosedur dalam mengidentifikasi nasabah, penerapan kebijakan dan prosedur pemantauan terhadap rekening dan transaksi nasabah, penerapan kebijakan dan prosedur manajemen risiko yang berkaitan dengan prinsip mengenal nasabah. Penelitian ini merupakan penelitian hukum normatif. Pendekatan masalah yang digunakan adalah pendekatan Undang-Undang dan pendekatan konseptual. Sumber bahan hukum menggunakan bahan hukum primer dan bahan hukum sekunder. Berdasarkan hasil penelitian dan pembahasan diperoleh kesimpulan bahwa di dalam pelaksanaannya prosedur identifikasi nasabah dalam rangka penerapan prinsip mengenal nasabah tidak hanya secara prosedur pada umumnya dalam Peraturan Bank Indonesia Nomor 3/ 10/ PBI/2001 tetapi juga harus bisa menggali lebih dalam tentang nasabah itu sendiri, karena kecanggihan teknologi saat ini juga menunjang terjadinya tindak pidana pencucian uang dengan berbagai macam bentuk, sehingga bank juga harus bisa menganalisa lebih detail tentang karakteristik nasabah demi mengantisipasi atau mencegah munculnya celah yang bisa mengakibatkan terjadinya tindak pidana pencucian uang.
\end{abstract}

Kata Kunci: Bank, prinsip mengenal nasabah, tindak pidana pencucian uang 


\section{Pendahuluan}

Perbankan sebagai suatu lembaga kepercayaan masyarakat memegang peranan penting dalam system perekonomian. Lembaga perbankan berperan sebagai perantara yang memiliki fungsi menerima simpanan dari pihak-pihak yang memiliki kelebihan dana baik itu orang perserongan ataupun badan hukum, dimana simpanan dana itu bisa disalurkan pada pihak yang memerlukan dana melalui pinjaman atau kredit.

Perbankan merupakan media dalam berbagai kebijakan moneter yang ditetapkan oleh otoritas moneter. Selain sebagai penyimpan dan penyalur dana, bank juga memiliki fungsi dalam hal memfasilitasi aliran barang dan jasa dari produsen kepada konsumen maupun melakukan berbagai aktivitas keuangan untuk kepentingan pemerintah. Perbankan juga bertindak sebagai perantara dalam berbagai kegiatan valuta asing, menyediakan jasa dalam letter of credit maupun dalam pelaksanaan system pembayaran internasional. Fungsi-fungsi bank tersebut menunjukkan bahwa system perbankan dari suatu negara memegang peranan sangat penting dalam menggerakkan roda perekonomian. Salah satu ciri sistem perbankan yang sehat dan efisisen yaitu dapat memelihara kepentingan masyarakat nasabah dengan baik, yang merupakan pilar kegiatan industry perbankan. ${ }^{1}$

Kegiatan perbankan bergerak dengan dana dari masyarakat atas dasar kepercayaan, oleh karena itu bank wajib menjaga kepercayaan masyarakat tersebut dan kepercayaan itu akan terjaga apabila sektor perbankan itu diselenggarakan dan dikelola dengan prinsip kehati-hatian sehingga selalu terpelihara kondisi kesehatannya. Untuk mewujudkannya maka dalam hal ini Bank Indonesia juga berkewajiban untuk melakukan pembinaan dan pengawasan terhadap bank-bank yang berada di bawah naungan Bank Indonesa seperti yang tercantum dalam Pasal 29 ayat (1) Undang-Undang Nomor 10 Tahun 1998 tentang Perubahan atas Undang-Undang Nomor 7 Tahun 1992 tentang Perbankan. Hubungan perbankan antara bank dan dan nasabah bank harus dilandasi prinsip kemitraan (kesejajaran) yang dijabarkan

\footnotetext{
${ }^{1}$ Djoni S Gahzali, Hukum Perbankan, Jakarta : Sinar Grafika, 2010, hlm. 24
} 
lebih lanjut melalui prinsip kepercayaan (fiduciary principle), prinsip kehatihatian (prudential principle), dan prinsip kerahasiaan (confidential principle) serta prinsip menganal nasabah (know your customer principle). ${ }^{2}$

Pelayanan jasa perbankan yang utama adalah penghimpunan dana dan pemberian kredit, walaupun banyak juga jenis jasa-jasa lain yang ditawarkan oleh bank. Penghimpunan dana yang dilakukan oleh perbankan berupa simpanan giro, deposito berjangka, sertifikat deposito, tabungan, dan atau bentuk lain yang dipersamakan dengan itu. Bentuk lainnya yang dipersamakan dengan itu dimaksudkan untuk menampung kemungkinan adanya bentuk penghimpunan dana dari masayarakat oleh bank perkereditan rakyat yang serupa dengan deposito berjangka dan tabungan, tetapi bukan giro atau simpanan lain yang dapat ditarik dengan cek.

Dalam kegiatan usahanya bank dihadapkan pada berbagai resiko antara lain resiko reputasi, resiko operasional, resiko hukum dan resiko terkonsentrasinya transaksi. Dalam rangka mengelola resiko yang mungkin timbul maka bank wajib menerapkan prinsip kehati-hatian dalam melakukan kegiatan operasional. Prinsip kehati-hatian itu tidak hanya berlaku untuk pemberian kredit saja seperti yang dikenal dengan istilah $5^{\prime} \mathrm{C}$ tetapi juga berlaku dalam hal penghimpunan dana. Salah satu upaya dalam melaksanakan prinsip kehati-hatian dalam penghimpunan dana adalah penerapan prinsip mengenal nasabah (know your customer).

Bank harus mengetahui karakter dan identitas dari nasabahnya karena dengan mengetahui karakter nasabahanya dengan baik maka bank dapat terhindar dari penyalahgunaan jasa oleh nasabahnya. Penyalahgunaan dalam hal ini berupa tindak pidana perbankan. Dimensi bentuk tindak pidana perbankan bisa berupa tindak kejahatan seseorang terhadap bank, tindak kejahatan bank terhadap bank lain ataupun kejahatan bank terhadap perorangan sehingga bank dapat menjadi korban ataupun pelaku.

\footnotetext{
${ }^{2}$ Ibid, hlm. 26
} 
Kualifikasi bentuk tindak pidana perbankan ada dua jenis, yaitu kejahatan dan pelanggaran. Secara garis besarnya bentuk kejahatan dan pelanggaran yang sering terjadi di bidang perbankan, diantaranya: ${ }^{3}$

1.1. Penipuan atau kecurangan di bidang perkreditan.

1.2. Penggelapan dana-dana masyarakat.

1.3. Penyelewengan atau penyalahgunaan dana-dana masyarakat.

1.4. Pelanggaran terhadap peraturan-peraturan keuangan.

1.5. Pencucian uang (money laundering).

Pencucian uang atau money laundering adalah hal yang patut diwaspadai oleh bank, karena bank sebagai sarana penyimpan dana sangat dimungkinkan sekali terjadinya money laundering. Bank harus tegas dalam menerapkan prinsip kehati-hatian dalam melakukan penghimpunan dana karena tidak mungkin bank menjadi korban dari adanya money laundering tersebut dan dalam hal ini prinsip mengenal nasabah sebagai salah satu prinsip kehati-hatian harus berperan penuh dalam mencegah terjadinya money laundering. Oleh karena itu melalui artikel ini digali lebih dalam tentang sejauh mana peranan prinsip mengenal nasabah dalam mencegah terjadinya money laundering dan apa saja hambatan yang mungkin terjadi dalam penerapannya.

\section{Rumusan Masalah}

2.1. Upaya apa yang dilakukan oleh bank dalam menerapkan prinsip mengenal nasabah untuk mencegah terjadinya money laundering.

2.2. Faktor apa yang menjadi penghambat dalam penerapan prinsip mengenal nasabah.

\footnotetext{
${ }^{3}$ Muhammad Djumhana, Hukum Perbankan di Indonesia, Citra Aditya Bakti : Bandung, 2006, hlm. 585
} 


\section{Tujuan Penelitian}

3.1. Untuk mengkaji secara mendalam upaya yang dilakukan oleh bank dalam menerapkan prinsip mengenal nasabah untuk mencegah terjadinya money laundering.

3.2. Untuk mengkaji secara mendalam faktor yang menjadi penghambat dalam penerapan prinsip mengenal nasabah.

\section{Metode Penelitian}

4.1.Jenis penelitian

Jenis penelitian yang digunakan dalam karya tulis ini adalah legal research yaitu penelitian yang difokuskan untuk mengkaji penerapan-penerapan kaidah-kaidah atau norma-norma dalam hukum positif yang berlaku. Selain itu legal research juga dilakukan dengan cara mengkaji berbagai aturan hukum yang bersifat formil seperti peraturan perundang-undangan serta literatur yang berisi konsep teoritis yang kemudian dihubungkan dengan permasalahan yang akan dibahas dalam karya tulis ini.

\subsection{Pendekatan Masalah}

4.2.1. Pendekatan Undang-Undang (statue approach) dilakukan dengan menelaah semua Undang-Undang dan regulasi yang bersangkut paut dengan isu hukum yang sedang ditangani. Pendekatan Undang-Undang akan membuka kesempatan bagi peneliti untuk mempelajari konsistensi dan kesesuaian antara suatu UndangUndang dengan Undang-Undang lainnya atau antara UndangUndang dengan Undang-Undang dasar atau antara regulasi dan Undang-Undang. ${ }^{4}$

4.2.2. Pendekatan konseptual (conseptual approach) ialah pendekatan yang beranjak dari pandangan-pandangan dan doktrin-doktrin yang berkembang dalam ilmu hukum. Dengan mempelajari pandanganpandangan dan doktrin-doktrin yang berkembang dalam ilmu hukum akan ditemukan ide-ide yang melahirkan pengertian hukum,

\footnotetext{
${ }^{4}$ Peter Mahmud Marzuki ,Penelitian Hukum, Prenada Media Group, Jakarta, 2005, hlm.93.
} 
konsep-konsep hukum dan asas-asas hukum yang relevan dengan isu yang dihadapi. Pemahaman akan pandangan-pandangan dan doktrin-doktrin tersebut merupakan sandaran dalam membangun suatu argumentasi hukum dalam memecahkan isu yang dihadapi. ${ }^{5}$

4.3.Sumber Bahan Hukum

4.3.1. Bahan hukum primer (primary law material), adalah bahan hukum yang bersifat autoritatif, artinya mempunyai otoritas, yang terdiri dari perundang-undangan, catatan-catatn resmi atau risalah dalam pembuatan undang-undang dan putusan hakim ${ }^{6}$, dalam hal ini yang berkaitan dengan penelitian ini adalah:

4.3.1.1. Undang-Undang Dasar Republik Indonesia Tahun 1945

4.3.1.2. Undang-Undang Republik Indonesia Nomor 7 Tahun 1992 Tentang Perbankan

4.3.1.3. Undang-Undang Republik Indonesia Nomor 10 Tahun 1998 Tentang Perubahan Atas Undang-Undang Republik Indonesia Nomor 7 Tahun 1992 Tentang Perbankan

4.3.1.4. Undang-Undang Republik Indonesia Nomor 25 Tahun 2003 Tentang Tindak Pidana pencucian Uang

\subsubsection{Peraturan Bank Indonesia Nomor 3 /10/PBI/2001 Tentang Penerapan Prinsip Mengenal Nasabah}

4.3.2. Bahan hukum sekunder (secondary law material), meliputi semua publikasi tentang hukum yang bukan merupakan dokumen resmi. Publikasi tenang hukum ini meliputi buku-buku teks, skripsi, tesis, dan disertasi hukum. Disamping itu juga kamus-kamus hukum dan komentar-komentar atas putusan pengadilan. ${ }^{7}$ Bahan hukum sekunder juga dapat ditemukan dari sumber opini hukum dari para ahli yang dimuat di koran, artikel, majalah ataupun internet.

4.3.3. Bahan non hukum, dapat berupa kamus, atau literature-literature di luar ilmu hukum tetapi masih memiliki kaitan dengan apa yang 
hendak diteliti dan dibahas dalam penelitian ini. Dalam suatu penelitian hukum untuk keperluan akademis bahan hukum dapat membantu dan berguna juga untuk menambah wawasan mengenai ilmu-ilmu diluar ilmu hukum. ${ }^{8}$

\section{Hasil Penelitian dan Pembahasan}

\subsection{Upaya Bank Dalam Penerapan Prinsip Mengenal Nasabah}

Perbankan memegang fungsi bank selain sebagai penyimpan dan penyalur dana, bank juga memiliki fungsi dalam hal memfasilitasi aliran barang dan jasa dari produsen kepada konsumen maupun melakukan berbagai aktivitas keuangan untuk kepentingan pemerintah. Perbankan juga bertindak sebagai perantara dalam berbagai kegiatan valuta asing antara lain tukar menukar valuta domestic dengan valuta asing, menyediakan jasa dalam letter of credit maupun dalam pelaksanaa dan system pembayaran internasional. Perbankan juga merupakan media dalam berbagai kebijakan moneter yang ditetapkan oleh otoritas moneter,

Salah satu jenis pelayanan jasa perbankan adalah penghimpunan dana. Penghimpunan dana merupakan jasa utama yang ditawarkan dunia perbankan. Dana yang dihimpun dari masyarakat ini meruapakn suatu tulang punggung dari dana yang dikelola oleh bank untuk memperoleh keuntungan. Penghimpunan dana yang dilakukan oleh perbankan berupa simpanan giro, deposito berjangka, sertifikat deposito, tabungan atau bentuk lainnya yang dipersamakan dengan itu.

Dalam Pasal 1 angka 5 Undang-Undang Nomor 7 Tahun 1992 sebagaimana telah diubah dengan Undang-Undang Nomor 10 Tahun 1998 tentang Perbankan, simpanan didefinisikan sebagai dana yang dipercayakan oleh masyarakat kepada bank berdasarkan perjanjian penyimpanan dana dalam bentuk giro, deposito, sertifikat deposito, tabungan, dan atau bentuk lainnya yang dipersamakan dengan itu. ${ }^{9}$

\footnotetext{
${ }^{8}$ Ibid, hal 164

${ }^{9}$ Lihat Pasal 1 angka 5 Undang-Undang Nomor 7 Tahun 1992 sebagaimana telah diubah dengan Undang-Undang Nomor 10 Tahun 1998 tentang Perbankan.
} 
Berdasarkan definisi simpanan di atas maka dapat di jabarkan jenis-jenis simpanan yang ditawarkan bank, yaitu:

5.1.1. Giro, adalah simpanan yang penarikannya dapat dilakuka setiap saat menggunakan cek, bilyet giro, sarana perintah pembayran lainnya, atau dengan pemindahbukuan (Pasal 1 angka 6 Undang-Undang Nomor 7 Tahun 1992 sebagaimana telah diubah dengan Undang-Undang Nomor 10 Tahun 1998).

5.1.2. Deposito (berjangka), adalah simpanan dana berjangka yang penarikannya hanya dapat dilakukan pada waktu tertentu berdasarkan perjanjian nasabah penyimpan dengan bank (Pasal 1 angka 7 Undang-Undang Nomor 7 Tahun 1992 sebagaimana telah diubah dengan Undang-Undang Nomor 10 Tahun 1998).

5.1.3. Sertifikat deposito, adalah simpanan dalam bentuk deposito yang sertifikat bukti penyimpanannya dapat dipindahtangankan (Pasal 1 angka 8 Undang-Undang Nomor 7 Tahun 1992 sebagaimana telah diubah dengan Undang-Undang Nomor 10 Tahun 1998). Perbedaan antara sertifikat deposito dan deposito berjangka adalah jika sertifikat deposito merupakan surat berharga perbankan yang diterbitkan atas tunjuk (unjuk) tanpa nama pembelinya dalam rupiah, yang merupakan suatu pengakuan hutang dari bank dan dapt diperjualbelikan dalam pasar uang, selain itu bunga sertifikat deposito diberikan secara diskonto yaitu dibayar sekaligus dimuka pada saat pembelian.

5.1.4. Tabungan, adalah simpanan yang penarikannya hanya dapat dilakukan menurut syarat tertentu yang disepakai, tetapi tidak dapat ditarik dengan cek, bilyet giro, dan atau alat lainnya yang dipersamakan dengan itu (Pasal 1 angka 9 
Undang-Undang Nomor 7 Tahun 1992 sebagaimana telah diubah dengan Undang-Undnag Nomor 10 Tahun 1998).

5.1.5. Dalam kegiatan usahanya bank dihadapkan pada berbagai resiko antara lain: ${ }^{10}$

5.1.6. Operational risk, artinya resiko bank tidak dapat melakukan operasionalnya secara normal, yang antara lain disebabkan adanya ketidakcukupan dan/atau tidak berfungsinya proses internal, kesalahan manusia, gangguan dan kegagalan system informasi manajemen dan komunikasi, ketidakpastian ketentuan, kelemahan struktur pengendalian, adanya problem eksternal, atau adanya hal-hal yang bersifat force majeur, seperti bencana alam, kebakaran, dan lainlain.

5.1.7. Legal risk, artinya resiko yang disebabkan oleh adanya kelemahan aspek yurids, seperti antara lain adanya tuntutan hokum, ketiadaan pertauran perundang-undangan yang medukung atau kelemahan perilaku seperti tidak terpenuhinya syarat syahnya kontrak dan perikatan agunan tidak sempurna.

5.1.8. Concentration risk, artinya resiko yang terjadi karena bank menerima dana-dana dari pihak ketiga dalam jumlah besar yang terkonsentrasi pada beberapa nasabah.

5.1.9. Reputation risk, artinya resiko yang antara lain disebabkan adanya publikasi negative yang terkait dengan kegiatan usaha bank atau persepsi negative terhadap bank.

Dalam rangka mengelola resiko yang mungkin timbul maka bank wajib menerapkan prinsip kehati-hatian dalam melakukan kegiatan operasional. Salah satu upaya dalam melaksanakan prinsip kehati-hatian dalam penghimpunan dana adalah penerapan prinsip mengenal nasabah

\footnotetext{
${ }^{10}$ www.bi.go.id/id/peraturan/kodifikasi/bank/Documents/f2e4174bf76e404bb17df8ac94270 49eKodifikasiManajemenRisiko.pdf
} 
(know your customer). Bank harus mengetahui karakter dan identitas dari nasabahnya karena dengan mengetahui karakter nasabahanya dengan baik maka bank dapat terhindar dari penyalahgunaan jasa oleh nasabahnya. Penyalahgunaan dalam hal ini berupa tindak pidana perbankan. Salah satu jenis tindak pidana perbankan yang rawan terjadi adalah pencucian uang (money laundering).

Keterlibatan bank dalam kegiatan pencucian uang disebabkan adanya kemudahan proses untuk mengelola hasil kejahatan dalam berbagai kegiatan usaha bank antara lain ditempatkan dalam bentuk simpanan (deposito, tabungan, dan giro), menempatkannya dalam instrument keuangan misalnya pembelian sertifikat bank Indonesia, penggunaan safe deposit box, dan lain-lain.

Definisi pencucian uang sendiri menurut Pasal 1 ayat (1) UndangUndang Nomor 25 Tahun 2003 adalah :

"Perbuatan menempatkan, mentransfer, membayarkan, membelanjakan, menghibahkan, menyumbangkan, menitipkan, membawa ke luar negeri, menukarkan, atau perbuatan lainnya atas harta kekayaan yang diketahuinya atau patut di duga merupakan hasil tindak pidana dengan maksud untuk menyembunyikan, atau menyamarkan asal usul harta kekayaan sehingga seolaholahmenjadi harta kekayaan yang sah."

Dalam rangka mencegah terjadinya pencucian uang, maka bank harus menerpakan prinsip mengenal nasabah. Sehubungan dengan penerapan prinsip mengenal nasabah, maka bank Indonesia mengelaurkan Peraturan Bank Indonesia Nomor 3/10/ PBI/2001 tentang Penerapan Prinsip Mengenal Nasabah (Know Your Customer) sebagaimana telah diubah dengan Peraturan Bank Indonesia Nomor 3/23/PBI/2001 dan Peraturan Bank Indonesia Nomor 5/21/PBI/2003.

Prinsip mengnal nasabah (know your customer principle) menurut PBI No.3/10/PBI/2001 tentang Penerapan Prinsip Mengenal Nasabah dan PBI No.3/23/PBI/201 tentang Perubahan atas Peraturan Bank Indonesia No.3/1/PBI/2001 tentang Penerapan Prinsip Mengenal Nasabah (know your customer principle) adalah prinsip yang diterapkan bank untuk 
mengetahui identitas nasabah, memantau kegiatan transaksi nasabah termasuk perlaporan transaksi mencurigakan.

Kewajiban pemantauan identitas, transaksi serta rekening nasabah (record keeping obligations) yang kemudian dilaporkan kepada PusatPelaporan dan Analis Transaksi Keuangan (PPATK) sehingga tercipta suatu database informasi yang dapat dipergunakan oleh PPATK dan penegak hokum untuk menelusuri proses terjadinya money laundering sehingga memudahkan penegak hokum untuk melakukan investigasi lebih lanjut.

Baik dalam PBI yang mengatur tentang prinsip mengnal nasabah maupun dalam UU tindak pidana pencucian uang, bank diwajibkan melaporkan apabila ada transaksi yang dianggap mencurigakan kepada PPATK. Kategori transaksi yang diangap mencurigakan disini adalah :

5.1.1. Transaksi keuangan yang menyimpang dari profil, karakteristik atau kebiasaan pola transaksi dari nasabah yang bersangkutan.

5.1.2. Transaksi keuangan yang patut diduga dilakukan dengan tujuan untuk menghindari pelaporan transaksi yang bersangkutan yang wajib dilakukan oleh penyedia jasa keuangan.

5.1.3. Transaksi keuangan yang dilakukan atau batal dilakukan dengan menggunakan harta kekayaan yang diduga berasa dari hasil tindak pidan,seperti korupsi, dll.

Dengan ditetapkannya ketentuan-ketentuan tersebut maka petugas bank diibaratkan penyelidik/polisi yang memastikan pembukaan rekening oleh calon nasabah dilakukan setelah bank mempunyai keyakinan atas kredibilitas yang bersangkutan, dan rekeningnya dipergunakan untuk kepentingan usahanya maupun kepentingan pribadi. 
Dalam rangka pemantauan terhadap rekening dan transaksi nasabah, bank harus melakukan verifikasi yang lebih ketat terhadap :

5.1.1. Calon nasabah yang berasal dari negara yang diklasifikasikan sebagai high risk countries atau negara yang belum/ tidak menerpakan ketentuan prinsip menganl nasabah.

5.1.2. Bidang usaha ynag potensial digunakan sebagai saran pencucia uang.

5.1.3. Calon nasabah yang mempunyai resiko tinggi, seperti pejabat pemerintah, politikus, pimpinan negara, pejabat pengadilan atau militer, dan pejabat eksekutif bdan usaha milik pemerintah, anggota legislative,dll.

Untuk menghindari adanya pemalsuan informasi dan data-data nasabah, bank bila perlu melakukan kunjungan setempat untuk meneliti kondisi kegiatan usaha nasabah apakah memang sesuai dengan apa yang telah diinformasikan oleh nasabah. Selain itu bank juga harus yakin bahwa dokumen yang diserahkan oleh nasabah adalah dokumen asli terutama yang terkait dengan identitas nasabah dan bank juga harus berhati-hati dengan nasabah yang tidak mau menyerahkan dokumen yang diperlukan.

Bank dalam penerapan prinsip mengnal nasabah harus benar-benar memiliki analisis yang baik terhadapa calon nasabahnya, apalagi jika nasabahnya adalah nasabah yang bukan perorangan melainkan nasabah yang berupa perusahaan. Bank juga harus mempunyai kemampuan untuk mengidentifikasi antara lain terkait dengan negara asal calon nasabah (jika nasabah adalah orang asing) contohnya, apakah negara calon nasabah adalah negara yang termasuk dalam jalur perdagangan narkoba atau tidak, kemudian harus bisa mengidentifikasi calon nasabah apabila dalam pembukaan rekening untuk tujuan usaha, nasabah menolak untuk memberikan informasi yang jelas terkait dengan tujuan usahanya. 
Bank juga harus bisa mengidentifikasi elektronik transfer dalam jumlah besar tanpa alasan yang jelas, tidak sesuai dengan kegiatan usaha nasabah dan karakteristik rekening nasabah, pembayaran atau penerimaan atau penjualan barang atau pemberian jasa yang tidak terkait dengan kegiatan usaha nasabah, dll.

Jasa bank yang bersifat elektronis dan jasa keuangan yang tidak saling bertatap muka cukup rawan terhadap kejahatan pencucian uang, begitu juga dengan pengambilan tunai, penyimpanan dan transfer dana melalui ATM. Sehingga bank sebagai penyedia jasa keuangan yang menyediakan jasa melalui elektronik, baik berupa internet banking, $\mathrm{M}$ banking dll, harus memiliki keyakinan terhadap identitas nasabah jadi bank teap harus bertatap muka dengan nasabah sebelum pembukaan rekening dilakukan dan bank juga harus memantau dan mengidentifikasi jika transaksi yang dilakukan oleh nasabah termasuk transaksi yang mencurigakan.

Jelasnya bank selaku penyeda jasa keuangan harus bisa menerapkan proses identifikasi nasabah terhadapa nasabah tanpa kecuali, walaupun kewajiban ini tidak berlaku bagi walk in customer, yaitu pihakpihak yang menggunakan jasa bank tanpa memiliki rekening di bank tersebut (non account holder), sepanjang nilai transaksi yang dilakukan tidak melebihi Rp. 100.000.000,- (seratus juta rupiah) atau nilai yang setara dengan itu.

Prosedur identifikasi nasabah dalam rangka penerapan prinsip mengnal nasabah tidak hanya secara prosedur pada umumnya dalam pembukaan rekening seperti yang tercantum dalam Pasal 4, 5, 6, Peraturan Bank Indonesia Nomor 3/ 10/ PBI/2001 tentang Penerapan Prinsip Mengnal Nasabah tetapi juga harus bisa menggali lebih dalam tentang nasabah itu sendiri, karena tidak dapat dimungkiri kecanggihan teknologi saat ini juga menunjang terjadinya tindak pidana pencucian uang dengan berbagai macam bentuk, sehingga bank juga harus bisa menanalisisa lebih detail tentang karakteristik nasabah demi 
mengantisipasi atau mencegah munculnya celah yang bisa mengakibatkan terjadinya tindak pidana pencucian uang.

\subsection{Faktor-Faktor yang Menjadi Hambatan dalam Penerapan Prinsip Mengenal Nasabah}

Penerapan prinsip mengenal nasabah oleh bank seringkali dilanggar sendiri oleh bank, sehingga terdapat celah untuk terjadinya tindak pidana pencucian uang. Terbongkarnya kasus-kasus korupsi beberapa tahun terkahir ini juga mengakibatkan terbongkarnya aliran dana korupsi yang ada di bank-bank. Hal itu membuktikan bahwa bank ternyata belum aware atau mewaspadai adanya aliran dan yang mencurigakan pada setiap rekening, dan hal itu juga membuktikan bahwa bank belum terlalu serius dalam menerpakan prinsip kehati-hatian khusunya prinsip mengenal nasabah.

Kegagalan bank dalam dalam menrapakan kebijakan dan system tersebut juga diakibatkan bebrapa faktor sehingga penerapan prinsip mengenal nasabah tidak dapat dijalankan dengan bank dengan sungguhsungguh.Adapun faktor tersebut pada akhirnya menjadi kendala dan hambatan bagi bank untuk menerapkan prinsip menganal nasabah dengan ketat. Faktor-faktor itu timbul dari internal bank itu sendiri juga timbul dari masayarakat. Faktor yang timbul dari internal bank itu sendiri antara lain:

Rasa takut akan kehilangan nasabah apabila bank menerapkan prinsip mengenal nasabah secara penuh dan tegas. Kekhawatiran tersebut dapat dimaklumi mengingat kurangnya perhatian dari nasabah dan tidak adanya keseragaman antara bank yang satu dengan bank lainnya dalam menerapkan prinsip mengenal nasabah. Contohnya ada nasabah yang enggan menabung pada bank tertentu yang membuat aturan terlalu ketat dalam hal penerapan prinsip mengenal nasabah. Kondisi ini memberikan peluang kepada nasabah untuk memberikan informasi dan juga dimungkinkan nasabah berpindah pada bank yang tidak menerapkan prinsip mengenal nasabah dengan ketat. 
Skala usaha bank, salah satu faktor penghambat bank dalam menerapkan prinsip mengenal nasabah. Sebagai contoh salah satu bank terbesar di Indonesia memiliki karyawan yang sangat banyak dengan jumlah kantor cabang yang banyak pula dan otomatis memiliki nasabah yang jumlahnya juga sangat besar sekali. Kondisi tersebut tentu saja mempengaruhi efektifitas dalam melakukan penerapan prinsip mengenal nasabah, karena diperlukan persiapan yang cukup panjang baik dari segi waktu, dana dan keahlian dalam mempersiapkan penerapan prinsip tersebut dalam praktek perbankan, seperti pendataan profile dari seluruh nasabah yang ada, pelatihan untuk karyawan dan system informasi yang memadai.

Ketidaksiapan dalam penerapan prinsip mengenal nasabah. Sebagian besar bank masih belum memiliki dan dan keahlian yang cukup memadai yang diperlukan untuk membangun system informasi sebagai penunjang pendataan profile nasabah.

Sedangkan factor yang timbul dari masyarakat adalah tidak adanya perhatian dari nasabah terhadap peraturan prinsip mengenal nasabah yang diterapkan oleh bank. Kendala ini merupakan kendala utama yang dihadapi seluruh bank-bank dalam menerapkan prinsip mengenal nasabah. Selama nasabah belum memiliki kemauan untuk bekerja sama dengan memberikan informasi yang dibutuhkan, maka bank juga belum dapat menerapkan seluruh ketentuan prinsip mengenal nasabah. Kesulitan bank dalam mengajak kerja sama nasabah dalam penerapan prinsip menganal nasabah antara lain disebabkan oleh :

5.1.1. Nasabah merasa tidak nyaman dan takut rahasia keuangannya diketahui pihak lain

5.1.2. Pengisian formulir merepotkan nasabah dan dirasa terlalu berlebihan, missal pada kolom jabatan, nama ibu kandung, dan lain-lain

5.1.3. Nasabah merasa tidak mendapatkan manfaat dari penerapan prinsip mengenal nasabah 
5.1.4. Nasabah merasa bank terlalu ingin tahu lebih dalam masalah internal nasabah

5.1.5. Nasabah yang memiliki dana di beberapa bank tidak bersedia mengisi form tentang prinsip mengenal nasabah dengan alasan bank lain tidak menerapkannya.

5.1.6. Selain itu hal-hal lain yang menjadi kendala bagi bank pada saat menerpakan prinsip menganal nasabah antara lain:

5.1.7. Nasabah tidak mau mengisi formulir dan mengancam akan memindahkan rekeningnya ke bank lain jika bank tetap memaksanya mengisi formulir tersebut.

5.1.8. Nasabah cenderung tidak jujur dalam pengisian data penghasilan baik itu sumber penghasilan ataupun jumlahnya

5.1.9. Nasabah berkeberatan untuk memberikan slip gajimya karena mereka beranggapan bahwa mereka nasabah penyimpan dana bukan peminjam dana.

Jadi seharusnya antara bank dan masyarakat itu sendiri harus memiliki kesadaran dan harus bisa bekerjasama dalam usaha mencegah terjadinya tindak pidana pencucian uang.

\section{Kesimpulan}

6.1. Bank dalam penerapan prinsip mengenal nasabah harus benar-benar memiliki analisis yang baik terhadapa calon nasabahnya. Prosedur identifikasi nasabah dalam rangka penerapan prinsip mengenal nasabah tidak hanya secara prosedur pada umumnya dalam Peraturan Bank Indonesia Nomor 3/10/PBI/2001 tetapi juga harus bisa menggali lebih dalam tentang nasabah itu sendiri, karena tidak dapat dimungkiri kecanggihan teknologi saat ini juga menunjang terjadinya tindak pidana pencucian uang dengan berbagai macam bentuk, sehingga bank juga harus bisa menanalisisa lebih detail tentang karakteristik nasabah demi mengantisipasi atau mencegah munculnya celah yang bisa mengakibatkan terjadinya tindak pidana pencucian uang. 
6.2. Kegagalan bank dalam menerapakan kebijakan dan system tersebut juga diakibatkan beberapa faktor sehingga penerapan prinsip mengenal nasabah tidak dapat dijalankan dengan bank dengan baik dan menjadi kendala dan hambatan bagi bank dalam menerapkan prinsip menganal nasabah Faktor itu timbul dari internal bank itu sendiri antara lain: Rasa takut akan kehilangan nasabah, skala usaha bank, Ketidaksiapan dalam penerapan prinsip mengenal nasabah. Sedangkan factor yang timbul dari masyarakat adalah tidak adanya perhatian dari nasabah terhadap peraturan prinsip mengenal nasabah yang diterapkan oleh bank. Nasabah belum memiliki kemauan untuk bekerja sama dengan memberikan informasi yang dibutuhkan, sehingga bank juga belum dapat menerapkan seluruh ketentuan prinsip mengenal nasabah. 


\section{DAFTAR PUSTAKA}

Sutedi, Adrian, Hukum Perbankan (Suatu Tinjauan Pencucian Uang, Merger, Likuidasi, dan Kepailitan), Jakarta : Sinar Grafika, 2010.

Djoni S Ghazali dan Rachmadi Usman, Hukum Perbankan, Jakarta : Sinar Grafika, 2010.

Djumhana, Muhammad, Hukum Perbankan di Indonesia, Bandung : Citra Aditya Bakti, 2006.

Usman, Rachmadi, Aspek-Aspek Hukum Perbankan di Indonesia, Gramedia Pustaka Utama, 2003.

Undang-Undang Republik Indonesia Nomor 7 Tahun 1992 tentang Perbankan.

Undang-Undang Republik Indonesia Nomor 10 Tahun 1998 tentang Perubahan Atas Undang-Undang Republik Indonesia Nomor 7 Tahun 1992 tentang Perbankan

Undang-Undang Republik Indonesia Nomor 25 Tahun 2003 tentang Tindak Pidana pencucian Uang

Peraturan Bank Indonesia Nomor 3 /10/PBI/2001 tentang Penerapan Prinsip Mengenal Nasabah

Peraturan Bank Indonesia Nomor 5/21/PBI/2003 tentang Perubahan Kedua Atas Peraturan Bank Indonesia Nomor 3 /10/PBI/2001 Tentang Penerapan Prinsip Mengenal Nasabah

www.bi.go.id/id/peraturan/kodifikasi/bank/Documents/f2e4174bf76e404bb17df8a c9427049eKodifikasiManajemenRisiko.pdf 